\title{
International Conference of Africanists 'Africa and Africans in National, Regional and Global Dimensions'
}

\section{Natalia A. Zherlitsina}

Institute for African Studies of the Russian Academy

of Sciences, Moscow

\section{Anna Yu. Sharova}

Institute for African Studies of the Russian Academy of Sciences, Moscow

\section{Natalia I. Bondar}

Institute for African Studies of the Russian Academy

of Sciences, Moscow

On 17-20 October 2017, the Institute for African Studies of the Russian Academy of Sciences hosted the $14^{\text {th }}$ African Studies Conference 'Africa and Africans in National, Regional and Global Dimensions'. In line with the long-standing tradition, every three years the conference brings together the Africanists from across the world to discuss a wide range of the continent's present-day problems and try to make forecasts for the future. As the Russia's main forum for the scholars of this scientific area, the conference provides an opportunity to get introduced to the relevant fundamental, regional and strategic research and discuss contemporary approaches and methods used within the African studies as an academic field.

The Africanists forum brought together participants from 23 countries. Thanks to the support provided by the Russian Foundation for Basic Research (grant 17-07-14005) and International goldmining company Nordgold and Squire Patton Boggs, the conference proved to be one of the most representative in its history: the Organising Committee had received at least 400 applications, including over 150 applications from international participants. Foreign participants 
came from seven African and ten European countries, as well as both North and South Americas and Australia. The Russian participants represented the following cities: Moscow, St. Petersburg, Yaroslavl, Kazan, Oryol, Voronezh, Nizhny Novgorod, Krasnoyarsk and Yekaterinburg.

Heads of the African countries' diplomatic missions in Moscow, representatives of the Ministry of Foreign Affairs of the Russian Federation, the State Duma, Federal Agency for Scientific Organisations (FANO), Federal Agency for the Commonwealth of Independent States, Compatriots Living Abroad and International Humanitarian Cooperation (Rossotrudnichestvo), Academy of Sciences' institutes and leading national universities attended the opening ceremony. The forum of Africanists was opened by Irina O. Abramova, Director of the Institute for African Studies of the Russian Academy of Sciences, corresponding member of the Russian Academy of Sciences. Following her address, A. M. Vasiliev, the Chairman of the Conference Organising Committee, Honorary President of the Institute for African Studies of the Russian Academy of Sciences, Member of the Academy, took the floor to moderate the plenary meeting. He greeted the attendees and gave the floor to M. L. Bogdanov, Deputy Foreign Minister of the Russian Federation, Special Presidential Envoy for the Middle East and Africa. The high-rank diplomat highlighted the importance of this international forum in strengthening the ties between Russia and the African continent. On behalf of the Department of Global Problems and International Relations of the Russian Academy of Sciences and Professor Council of the Russian Academy of Sciences, the Africanists were greeted by A. A. Gromyko, Director of the Institute of Europe of the Russian Academy of Sciences, corresponding member of the Russian Academy of Sciences. This was followed by the opening address of I. I. Abylgaziev, Director of the Institute of Asian and African Studies of the Moscow State University, one of the major talent pipelines for Russian Africanists and Orientalists. Deputy of the State Duma, member of the Foreign Affairs Committee A. V. Kananin assured the attendees that the conference findings would be examined in detail and used by the committee that he represents. Deputy Head of the Department for Coordination of Institutions in Social Sciences and Humanities of the Federal Agency for Scientific Organisations (FANO) D. I. Tsyganov expressed his best wishes of success and productive work to the conference participants. Ambassador of Zimbabwe Mike Nicholas Sango greeted the scholars on behalf of the diplomatic corps. On behalf of the Russian business 
community, representative of the Interstate Corporation for Development A. G. Gorobtsov highlighted the important role of science in promotion of economic cooperation between Russia and Africa.

The high standard of the scientific discussion was set by the plenary report 'The Potential of the African Continent in the Updated Development Strategy of the Russian Federation' presented by I. O. Abramova, Director of the Institute for African Studies of the Russian Academy of Sciences, corresponding member of the Russian Academy of Sciences. The report examined the current economic situation in Russia with due regard to the economic shocks of 2014-2017, i.e. financial sanctions and slide in oil prices. This context raises the significance of those Russia's partners that are more open and disposed to cooperation with Russia on the one hand, and possess a major growth resource and potential on the other. According to the speaker, these include the African countries. Abramova concludes that the current situation is characterised by an acute geo-economic and geopolitical struggle for Africa between the old and the new global economic actors. This increasing competition and rivalry concern the continent's resources, fastgrowing consumer goods and services markets in Africa, the intellectual potential and affinities of its fast-growing population (highest growth rates worldwide). Of equal importance are the political benefits resulting from productive economic cooperation with the African countries. Available forecasts indicate that by the 2030s, Africa will turn into the key global strategic reserve of raw supplies, virtually exclusive in significance. Professor Abramova is sure that the RussianAfrican economic cooperation may play a significant part in the longterm strategy of the Russian economic diversification, improving the export structure through shaping sustainable markets for the Russian industrial products. The list of the most promising cooperation areas covers electric power generation, mechanical engineering, chemical and pharmaceutical industries, advanced IT solutions and space industry. Africa and Russia need each other to achieve their development objectives, protect their national interests and ensure the prosperity of our countries and peoples.

The plenary meeting was continued by the report 'To Know the History of Our Guild - Our Common Past!' prepared by one of the Russia's most distinguished Africanists, Member of the Academy A. B. Davidson (National Research University - Higher School of Economics, Moscow). Davidson's report was devoted to the history of African studies in Russia. 
The conference included 44 panels divided into eight thematic sections: International Relations, Global Issues, Politics, Economics, Social Issues, Migration and Diasporas, Culture and Languages, and History.

The Politics section was highly topical and included nine panels, three of them covered the issue of regional conflicts that is relevant for the African countries. The panel 'The Roots of Contemporary Conflicts in the Horn of Africa' (chaired by A. Kumsa, Charles University, Prague, Czech Republic, and A. Degefa Nagawo, Addis Ababa University, Ethiopia) was devoted to various types of conflicts in the specified region. The panel 'Post-Conflict Reconstruction Crises: What Long-Term Future for Africa's Dysfunctional States?' (chaired by P. Englebert, Pomona College, Claremont, USA, and A. de Oliveira Rodrigues, School of Command and General Staff of the Army, Rio de Janeiro, Brazil) addressed the challenges of post-conflict reconstruction in the African countries, including DRC, Central African Republic, Somalia and Mali. The panel 'The Roots, Trends and Prospects of Radical Islamism in North and Sub-Saharan Africa' (chaired by E. V. Kharitonova, Institute for African Studies of the Russian Academy of Sciences, Moscow) assessed the risks of ideological radicalism in this region. Thus, V. V. Orlov (Institute of Asian and African Studies of the Moscow State University) analysed the new ambitions of Al Qaeda jihadist organisation in the Islamic Maghreb, N. A. Dobrobravin (St. Petersburg State University) highlighted the relationship between political instability and ethnicity by reviewing the case of the Tuaregs and Fulbe in West Africa.

Several panels of this section were dedicated to the issues associated with elections, strengthening of local authorities and political leadership. The challenges of multi-vector political change currently underway in most African countries were discussed at the panel 'Democratic Election Process in Africa: Progress, Paradoxes and Challenges' (chaired by A. Velthuizen, University of South Africa, Pretoria, and T. S. Denisova, Institute for African Studies of the Russian Academy of Sciences, Moscow). The report by S. Mantula (University of South Africa, Pretoria) analysed the national legal frameworks of South Africa, the Democratic Republic of Congo and South Sudan. The primary question raised by the author was whether progressive change in various African countries legal frameworks and constitutions would lead to real democratisation of the African societies. A. M. Katsina (U. M. Yar'adua University, Katsina, Nigeria) examined the interference and involvement of security establishments at various stages of election process in Nigeria. The report by A. Yu. Shipilov (Moscow State 
Institute of International Relations [University], Moscow) analysed the democratisation of Côte d'Ivoire electoral system. Yet, another topic of relevance for the African countries was discussed at the panel 'Strengthening Local Government' (chaired by M. Bell (George Washington University, McHenry, USA). The French scholar J.-L. Martineau (National Institute for Oriental Languages and Civilisations, Paris, France) highlighted the positive effects of traditional Yoruba festivals in Nigeria on the social activism of citizens, their involvement in the discussion of municipal, district-level and regional problems.

The Global Issues subject area was devoted to a wide range of issues: economic, informational and climatic globalisation in the continent countries, militant radicalism and global terrorism in Africa. The panel 'Globalisation and Africa: The Impact of Global Economic Integration on Africa in the $21^{\text {st }}$ Century' (chaired by: M. O. Okome, New York University, USA, P. Adebayo, E. Ojo, and A. T. Adewale, University of Ilorin, Nigeria) addressed the price that Africa has to pay for the Western tied aid. The scholars discussed whether any global economic integration imposing political and economic conditions in exchange for aid is anti-developmental in nature. The participants concluded that the foreign assistance burden like agreements on loans, economic and technical cooperation, allowable debt and other similar indices have increased the Africa's vulnerabilities rather than promoted its interests in the globalised market.

The International Relations section focused on Africa's ties with other regions, blocks and countries. The panel 'BRICS and Resistance in Africa: Thriving or Surviving?' chaired by J. van der Merwe (Stellenbosch University, South Africa) addressed the African countries' cooperation prospects within the BRICS framework. The report presented by young scholars E. R. Salakhetdinov and V. A. Sidorov (Institute for African Studies of the Russian Academy of Sciences, Moscow) considered the prospects of cooperation between Russia and South Africa in the domain of nuclear power industry. R. SteenkampFonseca (Stellenbosch University, South Africa) gave forecasts for the future of the BRICS Bank, new development finance and social grants in South Africa. Scholars from Europe, Africa and Russia took part in the panel 'The EU and Africa: Security - Development Nexus' (chaired by O. S. Kulkov, Institute for African Studies of the Russian Academy of Sciences, Moscow) that focused on political, economic, social and cultural ties between the EU and Africa. The Italian Africanists C. Mularoni and P. Scarpellini evaluated the activities of the European institutions supporting economic development in Africa. A. M. Rusero 
(Harare Polytechnic School of Journalism and Media Studies, Zimbabwe) spoke of the reasons for revision of the Trade Development Cooperation Agreement between the EU and South Africa.

The Social Issues section comprised seven panels devoted to a wide range of problems from vocational education, trade-unionism, and anticorruption efforts to the gender aspects of Africa's development. The panel 'Justice and Development in Contemporary Africa' (chaired by L. L. Fituni, corresponding member of the Russian Academy of Sciences, Institute for African Studies of the Russian Academy of Sciences, Moscow) focused on the issues concerning the strengthening legitimacy in the African countries as a prerequisite for the improvement of the continent's socio-economic climate. The report by I. O. Abramova (corresponding member of the Russian Academy of Sciences, Institute for African Studies of the Russian Academy of Sciences, Moscow) titled 'Legitimacy, Justice and Economic Growth in the Context of Africa's Development Goals in the $21^{\text {st }}$ Century' examined the changes in the nature, direction and strength of external (exogenous) effects on Africa's economy in 2007-2016. B. Rider (University of Cambridge, UK) spoke of promotion strategies for integrity in Southern Africa. The German scholar K. H. Lange (Institute for Transnational Studies, Landshut) raised a very relevant issue concerning the reasons for a rapid and relatively easy spread of the Islamic State's influence. Lange explains this phenomenon by arguing that national building in the relevant regions was initiated and implemented by notoriously authoritarian or dictatorial elites and never succeeded in penetrating the society as a whole. The failure of pseudo-national states provided good breeding ground for transnational ideologies.

The panel 'African Trade-Unionism in the $21^{\text {th }}$ Century - Coming of Age?' (chaired by M. Santos, Centre of African Studies, Porto University, Portugal) was aimed at synthesising the key features of the African trade-unionism over the last 50 years. C. Phelan (Kingston University London, UK) used nine West African Francophone countries to examine the effects of structural reform on the economic and political trade-unionism in Africa. R. M. Ferreira da Silva and R. M. Sampaio da Silva (Porto University, Portugal) analysed the activities of the teachers' unions in Guinea-Bissau and Mozambique. According to the scholars, the teachers' unions being the members of several national educational coalitions play an important part in defending the right to education. The panel 'Decolonial Education in South Africa' (chaired by E. Benyera, University of South Africa, Pretoria) was devoted to the issues of African education. The participants concurred 
that the current educational system in the African countries still requires reform. As long as the educational system is West-oriented and commercialised and the education is treated as a commodity, the African people, including its leaders, will be kept on the side-lines of global development. Z. Radebe (University of South Africa, Pretoria) analysed the reasons for student protests in South Africa in recent years and government's response to them. The problems discussed at the panel 'Security, Corruption and the African Development Discourse' (chaired by N. O. Arukwe, University of Nigeria, Nsukka) are highly relevant and important for the African societies. Corruption as a multifaceted phenomenon takes various shapes and is deleterious to the social, political and economic life of the African countries. Corruption is the 'curse of Africa' undermining the foundations of African security and hampering sustained development.

The Economics section was structured in two core streams: the role of new technologies and informal economy in Africa. The scholarly discussion at the panel 'New Technologies for Sustained Development of African Economies' (chaired by E. V. Morozenskaya, Institute for African Studies of the Russian Academy of Sciences, Moscow) was devoted to the institutional and financial arrangements required to secure technological progress in the African countries. V. V. Rybalkin (Federal Antimonopoly Service of the Russian Federation, Moscow) spoke about the import of ready-made foreign solutions for foreign companies' industrial facilities and promotion of R\&D activities domestically through government grants and international financial and research aid programmes. E. A. Bragina (Institute of World Economy and International Relations, Moscow) highlighted the need to boost the human capital development potential in Southern Africa, specifically education.

The Migration and Diasporas section was devoted to the acute problem of migration in various aspects. The panel 'Diaspora, Indigenous Investors, Economic Development and National Vision' (chaired by K. Krishna, University of Zambia, Lusaka) focused on the economic aspects of multiple African diasporas' influence. The report by C. Hocquet-Von Raesfeldt (National Institute for Oriental Languages and Civilisations, Paris, France) examined the economic activities of the Arabic, Greek, Armenian and Indian communities in Ethiopia in the first half of the $20^{\text {th }}$ century. The role of the Indian diaspora in the present-day economy of Zambia was considered by E. K. Chiputa (University of Zambia, Lusaka) who highlighted this community's role as one of the essential pillars in Zambia's post-1991 liberalised economy. 
The panel 'Migration Dynamics in Southern Africa' (chaired by R. M. Mukonza, Tshwane University of Technology, Pretoria, South Africa) addressed a relatively recent development: the expansion of South-South migration vs. the traditional South-North migration predominantly resulting from disparities in economic development. The spokespersons offered their explanations of this phenomenon. T. Ch. Chirimambowa and T. L. Chimedza (Institute for Public Affairs in Zimbabwe, Harare) examined migration from Zimbabwe to South Africa over the past 15 years and concluded that it was caused by failure of neoliberal experiments and loss of appeal of liberation movements and their ideas. A scholar from China, H. Pan (Peking University, China) provided his perspective on the Chinese economic migration to South Africa: he examined the migration of Shanghai people to South Africa in the early 1990s. L. Ekesson (University of Gothenburg, Sweden) considered the drivers of Portuguese post-colonial migration to Angola. The Portuguese migrating to Angola were encouraged by Angola's boosting economy against the background of recession and high unemployment rates in Portugal. T. Caravella (Administrative Appeals Tribunal, Bassendean, Australia) examined the relevant issue of migration from Southern Africa to Australia. He stressed the significance of the fact that as many as 1.6 per cent of Australia's population identify themselves as African Australians.

The scholars taking part in the panel 'Pan-Africanism and Migration' (chaired by D. M. Bondarenko, Doctor in History, corresponding member of the Russian Academy of Sciences, Institute for African Studies of the Russian Academy of Sciences, Moscow, and H. D. Weaver, Harvard University, Cambridge, USA) attempted to reveal the effects of panAfricanism on the mind-set of ethnic Africans beyond Africa, both at present and in the past. Having analysed the relations between African Americans and present-day migrants from Africa, D. M. Bondarenko (Institute for African Studies of the Russian Academy of Sciences, Moscow) pointed at profound differences of all kinds dividing the black natives of these two continents that took shape during the centuries of separation. In case of African Americans and Africans, the differences appear to be insurmountable and despite their common roots, these two groups are divided by major social disparities and cultural differences.

The Culture and Languages unit comprised six panels. The panel 'Human Sciences and Identity Studies for Cooperation and Development in Africa' chaired by Italian Africanists I. Micheli (University of Trieste) and M. Tosco (University of Turin) brought up an important subject: the need to preserve Africa's cultural diversity in the context 
of such global threats as climate change, migration, civil and economic wars and terrorism. The report by G. Borri (University of Turin, Italy) examined the World Health Organization work aiming at official recognition and support of African traditional medicine, including its original principles and practices.

The panel 'Languages of Africa: Traditions and Perspectives' (chaired by V. Ya. Porkhomovsky and A. B. Shluinsky, Doctor and $\mathrm{PhD}$ in Linguistics, Institute of Linguistics of the Russian Academy of Sciences, Moscow) was structured around several aspects: vocabulary and grammar of the African languages; comparative studies of the African languages; genealogical classification of the African languages; sociolinguistic studies of linguistic situations in Africa; language contacts in Africa. Representatives of the Moscow, St. Petersburg, Kazan and other scientific schools discussed the recent studies of the African languages, including the rare ones. A. P. Fattakhova ( $\mathrm{PhD}$ in Linguistics, Kazan Federal University, Kazan) presented a comparative study of Arabic numerals used in the Swahili and Tatar languages. S. B. Beletsky (Siberian Federal University, Krasnoyarsk) analysed the data collected through a field study of the Gogo language spoken in Central Tanzania. The report by Philippe Cassuto (Aix-Marseille University, France) and V. Ya. Porkhomovsky (Doctor in Linguistics, Institute of Linguistics of the Russian Academy of Sciences, Moscow) was devoted to the interpretation of the Old Testament in three different translations of the Bible in the Hausa language. W. Carstens (North-West University, Potchefstroom, South Africa) raised an important issue concerning the present-day linguistic situation and role of languages other than English in South Africa and tried to answer the question whether multilingualism is attainable in this country.

Traditions and innovations in the African art and studies thereof, issues relating to the presentation of the African art and material culture in anthropology museums, history and arts were the key subjects of the panel titled 'Tradition and Innovation: Insights into African Art' (chaired by A. Yu. Siim (Moskvitina), PhD in History, Museum of Anthropology and Ethnography [Kunstkamera], St. Petersburg). A. Schwartzott (North Carolina A\&T State University, Greensboro, USA) told the audience about a politically significant art project in Mozambique: local artists are transforming the weapons left over from the war of independence from Portugal (1962-1975) into contemporary works of art. The report by $\mathbf{P}$. A. Kutsenkov (PhD in History, Institute of Oriental Studies, Moscow) was devoted to the contemporary traditional art of the 
Dogons based on recent field research. K Simonson (Lithuanian Culture Research Institute, Lithuania) analysed the history of South African cinema and certain manifestations of racism and prejudice associated therewith.

The panel 'Russian Studies on Africa in the Past and Present: People, Problems, Theories, Perspectives' (chaired by A. B. Davidson, Doctor in History, member of the Russian Academy of Sciences, National Research University - Higher School of Economics, Moscow, and A. D. Savateev, Doctor in History, Institute for African Studies, Moscow) was dedicated to the history of Russian African studies and to their originators. Member of the Academy Davidson told the audience about the fortunes of the people who authored the first three $\mathrm{PhD}$ dissertations on African studies in the Soviet Union: 'The Jameson Raid (From the History of the 1899-1902 Second Boer War)', 'Rebellion in German Colonies in Africa', 'Russia and the Second Boer War'. N. V. Gromova (Doctor of Philosophy, Institute of Asian and African Studies of the Moscow State University, Moscow) paid tribute to the memory of G. K. Gromov who studied African languages in the 1930s. V. V. Bocharov (Doctor in History, St. Petersburg State University, Russia) reminded the audience about the brilliant theoretical legacy of the Leningrad school of African studies represented by D. A. Olderogge, N. M. Girenko and V. M. Misyugin. The report presented by A. S. Balezin (Doctor in History, Institute of World History of the Russian Academy of Sciences, Moscow) was titled 'Gera Ivanovna Potekhina as a Historian'.

The conference was closed with a cultural programme: the participants watched the African documentary titled 'Climbing the Ladder' that analysed antipoverty efforts in Ghana. This was followed by the concert of African music performed by the Russian and African musicians. The closing plenary meeting was moderated by I. O. Abramova, Director of the Institute for African Studies of the Russian Academy of Sciences, corresponding member of the Russian Academy of Sciences, and A. M. Vasiliev, Chairman of the Conference Organising Committee, Member of the Academy. Both the Russian and international participants took note of the high level of the conference and expressed their gratitude to the hosts. The conference provided yet another proof of its status as the Russian and international Africanists' key forum for a comprehensive discussion of Africa's problems. 